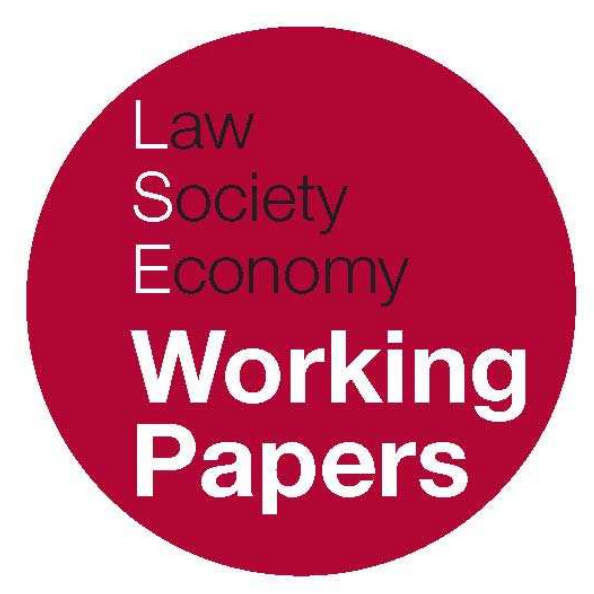

\title{
Legal Cosmopolitanism and the Normative Contribution of the Right to Development
}

\author{
Margot E. Salomon \\ LSE Law, Society and Economy Working Papers 16/2008 \\ London School of Economics and Political Science \\ Law Department

\begin{abstract}
This paper can be downloaded without charge from LSE Law, Society and Economy Working Papers at: www.lse.ac.uk/collections/law/wps/wps.htm and the Social Sciences Research Network electronic library at: http://ssrn.com/abstract $=1272582$.

(C) Margot E. Salomon. Users may download and/or print one copy to facilitate their private study or for non-commercial research. Users may not engage in further distribution of this material or use it for any profit-making activities or any other form of commercial gain.
\end{abstract}




\title{
Legal Cosmopolitanism and the Normative Contribution of the Right to Development
}

\author{
Margot E. Salomon*
}

\begin{abstract}
This essay unpacks the normative potential of the right to development in addressing contemporary disparities of the international political economy. Among the significant elements provided for in the UN Declaration on the Right to Development (1986) is its 'responsibilities approach': rather than establishing a new substantive right its provisions advance a system of international duties that might give better effect to existing socioeconomic rights. It challenges the classical reading of international human rights law that assigns merely secondary responsibility to developed states in fulfilling human rights elsewhere, in its place affirming a principle of complementary or shared human rights responsibility with developing states. While the Declaration articulates some unconventional demands for a human rights instrument the ways in which it frames the nature and scope of human rights duties is fitting under current conditions of economic globalisation. It is concerned with structural disadvantage that engenders the poverty afflicting half the global population today, and is preoccupied not with a state's duties to its own nationals, but with its duties to people in far off places. As is argued herein, this legal cosmopolitanism is critical to the realisation of human rights in the $21^{\text {st }}$ century.
\end{abstract}

\footnotetext{
* London School of Economics and Political Science, Centre for the Study of Human Rights \& Law Department. This essay is based on a paper presented at the Expert Meeting on Legal Perspectives involved in Implementing the Right to Development (Geneva, 4-6 January 2008) organised by the Program on Human Rights in Development of the Harvard School of Public Health (PHRID) and the Friedrich Ebert Stiftung (FES). The written contributions were compiled in order to inform the deliberations of the intergovernmental UN Working Group on the Right to Development at its ninth session in August 2008 and have been published in S. P. Marks (ed), Implementing the Right to Development: The Role of International Law (Geneva: PHRID \& FES, 2008). The full document is available online at http://www.fes globalization.org/geneva/documents/HumanRights/August08_Publication_RtD.pdf. I take this opportunity to thank the participants for their valuable insights on this subject, in particular my discussant Georges Abi-Saab. This submission draws on M. E. Salomon, Global Responsibility for Human Rights: World Poverty and the Development of International Law (Oxford: Oxford University Press, 2007).
} 


\section{INTRODUCTION}

This paper is concerned with the legal responsibilities of states for the violation of socio-economic rights globally. In particular, it considers the normative function of the right to development in offering a legal framework with the potential to humanise the global marketplace. It provides that the right to development has an important juridical contribution to make given the defining features of the international economic order, with the most salient element of this right found in its potential challenge to existing political and economic global arrangements. In this era of globalisation that seeks to provide for an international environment conducive to the further accumulation of wealth by the wealthy through the expansive tendencies of global capital, the right to development demands international cooperation under law for the creation of a structural environment favourable to the realisation of basic human rights, for everyone. It is what Georges Abi-Saab in his commentary on this paper referred to as an 'enabling right'.

Like the collective right of self-determination that preceded it, the right to development has both external and internal dimensions. The external dimension addresses disparities of the international political economy which evidence massive global inequities, ${ }^{1}$ and the consequent post cold war growth in social and material inequality between states. ${ }^{2}$ This aspect of the right engages the responsibilities of states internationally when acting individually or collectively. The internal dimension of the right to development focuses on the duties of each state to ensure domestic policies that seek to contribute to the realisation of the fundamental human rights of all its subjects. These two dimensions are to a great degree interrelated. As reflected in the 1986 United Nations Declaration on the Right Development (DRD) ${ }^{3}$ states have both 'the right and the duty to formulate

\footnotetext{
1 'One predetermined circumstance that most powerfully determines a person's opportunities for leading a healthy and productive life is his or her country of birth. Global inequities are massive. ... [G]lobal markets are far from equitable, and the rules governing their functioning have a disproportionately negative effect on developing countries.' World Bank, World Development Report 2006: Equity and Development (Washington, DC: World Bank/Oxford University Press, 2006) 16.

2 'For most of the world's poorest countries, the past decade has continued a disheartening trend: not only have they failed to reduce poverty, but they are falling further behind rich countries. Measured at the extremes, the gap between the average citizen in the richest and poorest countries is wide and getting wider. In 1990, the average American was 38 times richer than the average Tanzanian. Today, the average American is 61 times richer. ... [But] [p]art of the problem with the debate over global inequality is that it misses an important point. Income inequality is exceptionally high however it is measured and regardless of whether it is rising or falling.' UNDP, Human Development Report 2005: International Cooperation at a Crossroads: Aid, Trade and Security in an Unequal World (New York: Oxford University Press, 2005) 36-37. Inequality has risen within states as well, an aspect addressed, in part, by the internal dimension of the right to development. The UNDP provides that: '[T] here has been a clear trend over the past two decades towards rising inequality within countries. Of the 73 countries for which data are available, 53 (with more than 80 per cent of the world's population) have seen inequality rise, while only 9 (with 4 per cent of the population) have seen it narrow. This holds true in both high and low growth situations (such as China in the first case and Bolivia in the second) and across all regions.' ibid, 55.

${ }^{3}$ DRD, GA res A/RES/41/128, 4 December 1986, annex 41 UN GAOR Supp. (No. 53) 186, UN Doc A/RES/41/53 (1986).
} 
appropriate national development policies,' the 'right' being exercisable against the international community. ${ }^{4}$ Another particularity is that the Declaration is characterised by a 'responsibilities approach;' its articles focus on delineating duties rather than detailing rights. This element reinforces the appreciation that the right to development is less about establishing a new substantive right, and more about framing a system of duties that might give better effect to existing rights.

A brief sketch of the legal foundations of the international (ie external) obligations of states regarding inter alia the right to an adequate standard of living, the rights to food, health and education in developing countries reminds us that the external responsibilities of states have always been a core element in human rights treaties that address socio-economic rights. ${ }^{5}$ The United Nations (UN) Charter's emphasis on social justice and human rights linked those elements to a stable international order. ${ }^{6}$ The realisation of these common goals was recognised as requiring cooperation among states, and it is this tenet that constitutes the essence of this foundational treaty. Subsequent legal sources addressing international cooperation can be found in the Universal Declaration of Human Rights (UDHR), ${ }^{7}$ notably at Articles 22 and 28. Article 22 recognises that 'social security' - a right receiving increased attention as a response to market failures requires 'national effort and international co-operation.'8 Article 28 establishes the

\footnotetext{
${ }^{4} \mathrm{DRD}$, art 2(3). 'Appropriate' development policies, as per article 2(3), are those 'that aim at the constant improvement of the well-being of the entire population and of all individuals, on the basis of their active, free and meaningful participation in development and in the fair distribution of the benefits resulting therefrom.' And see, A. Orford, 'Globalization and the Right to Development' in P. Alston (ed), Peoples' Rights (Oxford: Oxford University Press, 2001) 137.

5 The broad categories of 'developing' and 'developed' countries are used here as shorthand to denote the affluent and poor parts of the world respectively, just as the WTO Deputy Director-General recently offered a long list of imbalances that would need to be corrected if the multilateral trading system were to be fair to 'developing countries', while recognising the range of cleavages and alliances within those two broad categories. V. Sendanyoye-Rugwabiza, 'Is the Doha Development Round a Development Round?' (London School of Economics, 31 March 2006).

${ }^{6}$ Charter of the United Nations (1945) entered into force 24 October 1945, 59 Stat. 1031, TS 993, 3 Bevans 1193.

7 Universal Declaration of Human Rights, GA res. 217A (III), 10 December 1948, UN GAOR, 3 Session Resolutions, pt. 1, 71, UN Doc A/810 (1948).

8 'The momentum of international agencies, transnational corporations and the global market compels modernisation and a realistic extension of social security, including social insurance.' See, P. Townsend, The Right to Social Security and National Development: Lessons from OECD Experience for Low-Income Countries, Discussion Paper 18 (Geneva: International Labour Organization, 2007) 2; 'TThus] access [to programmes that help individuals make employment transitions, and solid safety nets and assured access to basic services such as education and healthcare] must not vary with the ebb and flow of economic activity and personal circumstances. To have an open economy we may need a more protective one than we have had in the recent past.' D. Leipziger and M. Spence, 'Globalisation's Losers Need Support,' Financial Times (15 May 2007). (Leipziger is a vice-president at the World Bank).

Note also Article 25 UDHR: 'Everyone has the right to a standard of living adequate for the health and well-being of himself and of his family, including food, clothing, housing and medical care and necessary social services, and the right to security in the event of unemployment, sickness, disability, widowhood, old age or other lack of livelihood in circumstances beyond his control.' And, CESCR, General Comment No. 19 (Article 9) The Right to Social Security (39th session, 2007) UN Doc. E/C.12/GC/19.

Para 57: With regard to the conclusion and implementation of international and regional agreements, States Parties should take steps to ensure that these instruments do not adversely impact upon the right to social security. Agreements concerning trade liberalization should not restrict the capacity of a State Party to ensure the full realization of the right to social security.'
} 
entitlement of all to a just social and international order in which human rights can be realised.

The Declaration on the Right to Development makes a vital contribution in this area with duties of international cooperation informing its logic and shaping its structure: Article 3(1) provides that states have the primary responsibility for the creation of national and international conditions favourable to the realisation of the right to development; Article 3(3) refers to the duty of all states to cooperate with each other in ensuring development and eliminating obstacles to development. This is followed by Article 4(1) which refers to the duty of all states to take steps individually and collectively to formulate international development policies in order to facilitate the full realisation of the right to development. In Article 4(2) the DRD unambiguously accepts that effective international cooperation is essential '[a]s a complement to the efforts of developing countries [and] in providing these countries with appropriate means and facilities to foster their comprehensive development." Article 6(1) of the Declaration calls upon states to cooperate in promoting, encouraging, and strengthening universal respect for human rights and fundamental freedoms for all. Under Article 10, states acting nationally and internationally are enjoined to take 'steps to ensure the full exercise and progressive enhancement of the right through the formulation, adoption and implementation of policy, legislative and other measures.' As Ian Brownlie concluded in the years following the Declaration's adoption: 'the right constitutes a general affirmation of a need for a programme of international economic justice.'10

In binding human rights treaties we find obligations of 'international assistance and cooperation' at Article 2(1) of the International Covenant on Economic, Social and Cultural Rights (ICESCR), which are reaffirmed in the context of the right to an adequate standard of living (Article 11(1)) 11 and 'the

Para 58: 'States Parties should ensure that their actions as members of international organizations take due account of the right to social security. Accordingly, States Parties that are members of international financial institutions, notably the International Monetary Fund, the World Bank, and regional development banks, should take steps to ensure that the right to social security is taken into account in their lending policies, credit agreements and other international measures. States Parties should ensure that the policies and practices of international and regional financial institutions, in particular those concerning their role in structural adjustment and in the design and implementation of social security systems, promote and do not interfere with the right to social security.'

Para 61: 'The Committee also wishes to emphasize that it is particularly incumbent on States Parties, and other actors in a position to assist, to provide international assistance and cooperation, especially economic and technical, to enable developing countries to fulfil their core obligations.'

Para 82: 'Mnternational organizations concerned with trade such as the World Trade Organization, should cooperate effectively with States Parties, building on their respective expertise, in relation to the implementation of the right to social security.'

${ }^{9}$ Emphasis added.

10 I. Brownlie, 'The Human Right to Development' (1989) Commonwealth Secretariat, 8.

11 The qualification provided in article 11(1) - that international cooperation depends on 'free consent' should be weighed against what today constitutes 'maximum available resources' and repeated international commitments to address world hunger and to lift people out of abject poverty. Moreover, in a world witness to mass starvation and to a systemic global wealth divide the notion that attending to world poverty should rest on 'free consent' lacks any legitimacy. 
fundamental right of everyone to be free from hunger' (Article 11(2)). References to obligations of international cooperation for economic, social and cultural rights appear throughout the Convention on the Rights of the Child (CRC), which explicitly includes the requirement that 'particular account shall be taken of the needs of developing countries. ${ }^{12}$ International cooperation has found its most recent endorsement via the adoption of the Convention on the Rights of Persons with Disabilities, which, notably, anticipates ratification by regional organisations with the European Community having already signed. ${ }^{13}$

These articulations provide that the dominant members of the international community of states, or, in the words of the Committee on Economic, Social and Cultural Rights (CESCR), 'all those in a position to assist,',14 have not only a role but also a responsibility in contributing to the immediate realisation of the minimum essential level of socio-economic rights globally. ${ }^{15}$

The significance and interpretation of this responsibility is today informed by three central factors: 1) the impact on human rights derived of powerful actors external to the developing state advancing rules governing world markets that are widely criticised for being inequitable ${ }^{16}$ 2) the pervasive influence of international economic organisations that continue to espouse neoliberalism (or its more recent variant), ${ }^{17}$ and 3) the corresponding reduction in domestic autonomy that limits the ability of states - particularly poor and less influential states - to decide independently their own economic and social policies. ${ }^{18}$

12 International Covenant on Economic, Social and Cultural Rights (1966) entered into force 3 January 1976, GA res. 2200A (XXI); Convention on the Rights of the Child (1989) entered into force 2 September 1990, GA res. 44/25.

${ }^{13}$ Convention on the Rights of Persons with Disabilities and Optional Protocol (2006) entered into force 3 May 2008, GA res. A/RES/61/106.

${ }^{14}$ CESCR, Statement on Poverty and the International Covenant on Economic, Social and Cultural Rights (25th session, 2001) UN Doc E/C12/2001/10, [16].

15 While all countries, including poor and middle-income countries, have human rights obligations both domestically and internationally, certain responsibilities in the alleviation of world poverty - the cornerstone of the right to development - apply exclusively to developed countries and constitute an 'essential complement' to domestic efforts at fulfilling socio-economic rights.

${ }^{16}$ The World Bank notes: 'The rules that govern markets for labour, goods, ideas, capital, and the use of natural resources need to become more equitable. ... Changes will require, above all, greater accountability at the global level, with greater representation of poor people's interests in rule-setting bodies.' n 1 above, [223].

17 'The ideologically hegemonic position has been the neoliberal agenda (widely called the Washington Consensus). It calls for trade and financial liberalization, privatization, deregulation, openness to foreign direct investment, a competitive exchange rate, fiscal discipline, lower taxes, and smaller government.' (Footnote omitted). W. K. Tabb, Economic Governance in the Age of Globalization (New York: Columbia University Press, 2004) 3. The admission that the welfare benefits of globalisation were 'oversold' (see for example, P. Krugman, 'Globalisation and Welfare,' London School of Economics, 14 June 2007) lead to 'post-Washington Consensus' policies which have been described as 'maintain[ing] a neoliberal approach to globalization, pursuing privatization, liberalization and deregulation - although with some attention to institutional contexts and social consequences.' UN Research Institute for Social Development (UNRISD), 'The Sources of Neoliberal Globalization' (2002) Report of UNRISD Seminar on Improving Knowledge on Social Development in International Organizations II, 4.

${ }^{18}$ See further, M. E. Salomon, 'International Economic Governance and Human Rights Accountability' in M. E. Salomon, A. Tostensen, and W. Vandenhole (eds), Casting the Net Wider: Human Rights, Development and New Duty-Bearers (Antwerp: Intersentia, 2007) 153; H. Stokke, 'What is Left of State Responsibility?: Turning State Obligations into State Responsibility in the Field of Economic, Social and Cultural Rights' in M. Scheinin and M. Suksi (eds), Human Rights in Development, Yearbook 2002 (Leiden: 
Paramount among the legal questions that vex the meaningful application of an obligation of international cooperation for the realisation of economic, social and cultural rights is the interplay between the domestic and external nature of obligations. ${ }^{19}$ Despite the repeated codification of human rights obligations of 'international cooperation' (international assistance and cooperation), and regardless of the fact that the realisation of economic, social, and cultural rights is envisaged as giving rise to responsibilities for states other than the rights-holder's own, there remains a sense that these external obligations challenge the classical assumption of international human rights law which is rooted in the protection of individuals against abuse by their own state, as opposed to enhance its object and purpose.

At the heart of this classical model lies the legal premise that the primary obligation for the realisation of human rights, including economic, social and cultural rights, belongs to the developing state acting in its domestic capacity. The DRD (a document which is the result, of course, of political compromise) is consistent with human rights instruments in this regard. As per preambular paragraph 15, the primary responsibility for creating conditions favourable to the development of peoples and individuals lies with the state acting domestically. With regard to obligations to 'respect' and 'protect' human rights, there is little controversy in suggesting that the domestic state and the external states are simultaneously and to the same extent bound to refrain from violating socioeconomic rights (respect) and to ensure protection against violations by third parties over which they exercise authority (eg transnational corporations, international financial institutions). The controversy (both legal and political) arises when we speak of the positive obligations of external states to 'fulfil' ('to cooperate' in fulfilling) socio-economic rights elsewhere. ${ }^{20}$ In this case, the international (external) obligations are largely understood as secondary obligations, that is, they become relevant when the developing state (the primary duty-bearer)

\footnotetext{
Martinus Nijhoff Publishers and Nordic Human Rights Publications, 2005) 37. See also the recent statement by the UN Special Rapporteur on the Right to Food: 'We need to move towards a regime of international trade in agricultural products which facilitates, rather than impedes, the choices made at the national level about how to achieve food sovereignty, and which allows an adequate mix of national capacity for food production and openness to trade. We require a regime allowing appropriate flexibilities, and we need to put an end to trade-distorting policies.' O. De Schutter, Statement of the Special Rapporteur on the Right to Food, Special Session of the Human Rights Council on the Impact of the Global Food Crisis on the Right to Food (22 May 2008).

19 Political questions centre on concerns by Northern states that developing states will understand themselves to be relieved of their domestic obligations if too great a focus is placed on the international dimensions, and that any commitment to international cooperation is tantamount to a commitment to increased aid. See, M. E. Salomon, A. Tostensen, and W. Vandenhole, 'Human Rights, Development and New Duty-Bearers' in Salomon, Tostensen and Vandenhole (eds), ibid, 3; M. E. Salomon, 'Towards a Just Institutional Order: A Commentary on the First Session of the UN Task Force on the Right to Development' (2005) 23 Netherlands Quarterly of Human Rights 3, 424.

${ }^{20}$ This tripartite model delineating three types of obligations is now regularly applied by CESCR in its consideration of state obligations under ICESCR.
} 
is unable to fulfil the rights on its own $^{21}$ with the use of its 'maximum available resources, ${ }^{22}$ as treaties dealing with this matter require. ${ }^{23}$

In considering the normative content of the right to development this briefing note challenges the assumption that the contemporary obligations of external states to 'fulfil' socio-economic rights abroad are necessarily of a secondary nature. The gross inequality that characterises world poverty today, the power differential that accompanies it, and the reality of global economic interdependence, serve to erode the legitimacy of this model that assigns secondary as opposed to shared responsibility to a developed state to fulfil the basic rights, for example, to food, water, and health of people elsewhere.

The figures are important to this claim. Six million children in developing countries die annually from malnutrition; ${ }^{24}$ a person from a developing country dies of starvation every 3.6 seconds, the large majority of whom are children under the age of five; 25 women living in sub-Saharan Africa have a one in 16 chance of dying in pregnancy. ${ }^{26}$ What these appalling figures fail to disclose on their own is that these maternal deaths are 100 times more likely to occur in sub-Saharan Africa than in high income countries; ${ }^{27}$ only 10 per cent of the world's health resources service the needs of 90 per cent of the global population; ${ }^{28}$ while there is

21 Here I limit my reference to states that are unable to alleviate poverty, working from an assumption that if the global economic environment better facilitated poverty alleviation most states would avail themselves of that opportunity. In any event, whether a state is 'unable' versus 'unwilling' does not impact on the determination of external responsibility. As Wenar notes, 'the difference [between whether the primary responsibility-holder is unable or unwilling] concerns only the appropriateness of blaming or punishing the person with the responsibility. We blame and punish those unwilling to discharge their responsibilities; we excuse those who are unable. Yet the appropriateness of blame and punishment makes no difference to the assignment of secondary responsibility... You are just as responsible for rescuing the drowning child whether the man on the park bench is callous, or whether he is rather disabled.' L. Wenar, 'Responsibility and Severe Poverty' in T. W. Pogge (ed), Freedom from Poverty as a Human Right: Who Owes What to the Very Poor? (Oxford: Oxford University Press/UNESCO, 2007) 265.

22 An essential issue to consider is what constitutes international 'maximum available resources' and the moral, and legal, implications of failing to meet the standard. Maximum available resources at the international level are equated with the globally endorsed 0.7 per cent GNI in official development assistance. If rich countries were to honour that pledge severe poverty would be eradicated. Since giving up this modest degree of wealth among high-income countries that already have roughly 81 per cent of the global product is not in conflict with anything of comparable value, the failure to do so becomes impossible to defend. Moreover, this argument does away with any justification that under these conditions states owe a greater duty of care to their own compatriots, since relieving world poverty would require no sacrifice even remotely comparable. On morality and sacrifice see the influential essay, P. Singer, 'Famine, Affluence and Morality' (1972) 1 Philosopby and Public Affairs 3, 229.

${ }^{23}$ ICESCR art 2(1): 'Each State Party to the present Covenant undertakes to take steps, individually and through international assistance and co-operation, especially economic and technical, to the maximum of its available resources, with a view to achieving progressively the full realization of the rights recognized in the present Covenant by all appropriate means, including particularly the adoption of legislative measures.'

${ }^{24}$ UN Millennium Project, Fast Facts: Faces of Poverty (2005).

25 ibid.

26 ibid.

27 UNDP, Human Development Report 2003: Millennium Development Goals: A Compact Among Nations to End Human Poverty (New York: Oxford University Press, 2003) 8.

28 'An aspirin for Juelly is no longer good enough' Financial Times, (25 January 2005). See further, P. Hunt, Report of the Special Rapporteur on the Right of Everyone to the Highest Attainable Standard of Physical and Mental Health: Mission to Uganda, UN Doc E/CN4/2006/48/Add2, [63]. 
enough food to feed everyone on the planet, one in three (640 million) children in developing countries are malnourished;29 44 per cent of the world's population lives below a World Bank poverty line of US $\$ 2$ a day yet consumes only 1.3 per cent of the global product. ${ }^{30}$

\section{THE STRUCTURAL APPROACH TO HUMAN RIGHTS}

Disparities in income between nations have grown at a pace faster than ever before in recent history. ${ }^{31}$ In its 2006 World Development Report, the World Bank concluded that unequal opportunities are 'truly staggering on a global scale. ${ }^{32}$ These discrepancies in wealth and power reflect a human rights problem far beyond that which can be systematically remedied even by a good faith commitment of a poor state to fulfilling obligations at the domestic level, or by narrowly-framed extraterritorial obligations of states:33 'Obligations of international cooperation for socio-economic rights require something over and beyond obligations derived from the "extraterritorial" reach of a human rights convention; they call for proactive steps through international cooperation in securing these rights globally, rather than obligations attached reactively, that is, based on the impact of a state's activities on the people in foreign countries. ${ }^{34}$

The continued occurrence of world poverty cannot be disassociated from the global structural environment that produces and perpetuates it, and from the political economy that sustains it and provides some with a disproportionate opportunity for access to wealth. ${ }^{35}$ A 'structural approach' to the scope of obligations proposes that the skewed international economic environment, understood in terms of lack of influence in international trade and finance for the poorest members, and the liberalisation and integration of world markets that favour the powerful and affluent, by definition undermines the ability of less commanding states to give effect to human rights. This automatically triggers a

${ }^{29}$ WHO, Removing Obstacles to Healthy Development, World Health Organization Report on Infectious Diseases (Geneva: WHO, 1999).

${ }^{30}$ High-income countries, with far less people (955 million citizens), together consume 81 per cent of the global product. T. W. Pogge, 'World Poverty and Human Rights' (2005) 19 Ethics and International Affairs 1, 1. Pogge draws his figures from the World Bank, World Development Report 2003.

${ }^{31}$ M. B. Steger, Globalization: A Very Short Introduction (Oxford: Oxford University Press, 2003) 104.

$32 \mathrm{n} 1$ above, 6 .

33 This is not to suggest that developing states are relieved of taking steps to realise progressively economic, social and cultural rights, nor does it ignore the fact that domestic factors in developing countries play an important role in the increase or reduction of their poverty. Effective domestic policies, however, do not alter the fact that the international order is implicated in their success or failure. To drive home the point: 'Even if country-specific factors fully explain the observed variations in the economic performance of developing countries, global factors may still play a major role in explaining why they did not on the whole do much better or much worse than they did in fact.' T. W. Pogge, 'The First UN Millennium Development Goal: A Cause for Celebration?' (2004) 5 Journal of Human Development 3, 391.

${ }^{34}$ M. E. Salomon, Global Responsibility for Human Rights: World Poverty and the Development of International Law (Oxford: Oxford University Press, 2007) 6.

35 Salomon, Tostensen and Vandenhole, n 19 above, 10-11. 
complementary or shared responsibility among external states rather than a mere secondary obligation. Given the consensus on the growth of inter-state inequality and the growing gap between rich and poor, the burden of proof should not fall on a developing state to show that it is unable to meet the basic rights of its people before the responsibility of the international community is engaged. Rather, the current state of world poverty with its substantive and systemic inequality requires that the burden of proof is reversed: it should be for developed states to demonstrate prima facie that their policies and decisions - whether taken individually or collectively - are not hurting the world's poor. ${ }^{36}$

The moral cosmopolitanism of political theorists is instructive here. It is concerned with the bases, nature and scope of our duties to foreigners who are starving or otherwise deprived of necessities. ${ }^{37}$ In essence, it appraises the duty to ensure basic human rights and justice globally. ${ }^{38}$ Like other theories based on contemporary conditions of interdependence, a (strong) account of political cosmopolitanism is informed by the terms of economic globalisation whereby we rely on the same global environment for the satisfaction of our needs and thus those suffering from poverty under this global scheme have a claim against it, that is, against those who direct it.

For the purposes of this inquiry, we recognise an international legal framework that provides a normative basis for substantiating this argument; a framework that is strengthened when applied in the context of economic globalisation. Of course, it remains to be seen whether its legal (or political) force will be sufficiently robust to pose a challenge to the dominant forces and preferences that steer economic globalisation, as exemplified by the (other interstate) domain of trade liberalisation. ${ }^{39}$

\footnotetext{
36 Mutatis mutandis, see W. Vandenhole, 'EU and Development: Extraterritorial Obligations under the International Covenant on Economic, Social and Cultural Rights' in Salomon, Tostensen, and Vandenhole (eds), n 18 above, 90. For an elaboration of the position that the first obligation is for the relevant states to cooperate in remedying the violation of existing minimum essential socio-economic rights globally, with the subsequent obligation being to prevent their further deterioration, see M. E. Salomon, 'International Human Rights Obligations in Context: Structural Obstacles and the Demands of Global Justice' in B. A. Andreassen, and S. P. Marks (eds), Development as a Human Right: Legal, Political and Economic Dimensions (Cambridge, MA: Harvard School of Public Health - Harvard University Press, 2006), 115 et seq and Salomon, Global Responsibility for Human Rights, n 34 above, 189 et seq.

${ }^{37}$ See the helpful overview of cosmopolitanism, which derives from the Greek word kosmopolitess ('citizen of the world'), at http://plato.stanford.edu/entries/cosmopolitanism/\#2.

38 ibid. See C. Beitz, Political Theory and International Relations (Princeton, NJ: Princeton University Press, 1979); and T. W. Pogge (ed) Freedom from Poverty as a Human Right: Who Owes What to the Very Poor? (Oxford: Oxford University Press/UNESCO, 2007).

39 "Agriculture negotiations are the "engine" and central issue of the WTO Doha Development Agenda. The G-33, representing as many as 44 developing Members, is committed and persistent with its strategic objectives to ensure that the critical issues of food security, rural livelihood and rural development become an integral part of the agriculture negotiations (sic). The Group solemnly believes that addressing the problem of food and livelihood security as well as rural development constitutes a concrete expression of developing countries "right to development". G-33 Press Statement, Geneva, 11 October 2005 [1].
} 


\section{THE STRUCTURAL APPROACH TO HUMAN RIGHTS: A CONTRIBUTION OF THE RIGHT TO DEVELOPMENT}

Consistent with the ICESCR which preceded it, and followed by the entry into force of the Convention on the Rights of the Child a few years later, the DRD likewise entrenches the notion that states are duty-bearers not only at the national level, but at the international level as well. However, the Declaration takes the scope of duties a step further in seeking to provide a juridical framework for oftrepeated claims against the public international order, for the failure of our international economic arrangements to allow for an environment conducive to human-centred development for all.

Given the very structure of our current global order claims regarding violations of basic socio-economic rights can be understood as against not only (specific) states when acting individually or collectively on the international plane, but also as against the global institutional order as a whole, over which the wealthy and powerful states exercise effective control. ${ }^{40}$ The DRD is an important document for this new approach ${ }^{41}$ and the way in which we understand and address contemporary obligations, not merely of world poverty and underdevelopment, but crucially, of 'acquisition and affluence at the other extreme of the population experience, and the mechanics or agents of the entire distribution'. ${ }^{42}$

The DRD emerged in large part as a response to the call by developing countries for an international order in which effective international cooperation would reduce the perceived unfairness of the prevailing economic scheme. Reaffirming commitments to international cooperation for human rights and a rights-based international order, the Declaration gave legal expression to the notion that the ability of states to develop, and to fulfil their human rights

\footnotetext{
40 This brief paper cannot address the many issues to which these points give rise, including notably the bases for disaggregating global responsibility pertaining to collective state conduct for violations of socioeconomic rights (ie determining 'perfect' obligations). Elsewhere I have addressed this issue: 'While all states are to cooperate in order to contribute to the common objective of eradicating world poverty, the responsibility of a state for the creation of a just institutional economic order should be in accordance largely with its weight and capacity in the world economy. The content of this principle of common but differentiated responsibilities in the context of international cooperation for human rights provides the basis for four indicators that may assist in determining responsibility for world poverty. First, responsibility may be determined as a result of the contribution that a state has made to the emergence of the problem; second, as a result of the relative power it wields at the international level that is manifested as influence over the direction of finance, trade, and development (effective control); third, responsibility may be determined based on whether the given state is in a position to assist; and fourth, responsibility can be determined on the basis of those states that benefit most from the existing distribution of global wealth and resources.' (Footnotes omitted). n 34 above, Ch 5: Attributing Global Legal Responsibility, 193.

${ }^{41}$ This added value of the right to development was recognised even prior to the adoption of the Declaration. In a seminal 1979 article Abi-Saab wrote: '[T] he responsibility for the inability of a State to exercise its right to development is not so much that of any one State as that of the international economic system as a whole.' G. Abi-Saab, 'The Legal Formulation of the Right to Development' in R-J Dupuy (ed), The Right to Development at the International Level (The Hague: Sijthoff \& Noordhoof, 1980) 170. ${ }^{42}$ P. Townsend and D. Gordon, 'The Human Condition is Structurally Unequal' in P. Townsend and D. Gordon (eds), World Poverty: New Policies to Defeat an Old Enemy (Bristol: The Policy Press, 2002) xv.
} 
obligations, are constrained by the structural arrangements and actions of the (powerful members) of international community. The DRD places the claims of developing countries suffering from underdevelopment at the centre of the global political economy, where their calls for a structural environment conducive to the fulfilment of human rights might be heeded. As such, the Declaration demands not merely cooperation for the achievement of human rights central to the alleviation of poverty, but also changes to the system of structural disadvantage that characterises the current international order.

The DRD places people and their human rights at the centre of the processes and outcomes of national and international economic and development strategies. The way in which duties are framed in the Declaration is to require, on the one hand, that attention be focused nationally in order to provide a domestic environment in which equitable and sustainable poverty-reduction and development can be realised (participation, persons as beneficiaries of the right, interdependence of rights, equality of opportunity for all with a focus on an active role for women in development processes). ${ }^{43}$ As is clear, the Declaration has a contribution to make in conditioning domestic policy. ${ }^{44} \mathrm{But}$, on the other hand, central to its logic is the need for international cooperation in order to ensure that the external environment is supportive of this human-centred development process. Critically, responsibilities are understood also to devolve upon states acting at the international level, and, as per preambular paragraph 16 and Article 2(3) of the Declaration, developing states enjoy the prerogative to invoke this right as against the public international order on behalf of their people. ${ }^{45}$ That every single state does not formally recognise socio-economic rights, or the right to development, does not detract from the fact that the international community of states as a whole has shown itself to be committed, in principle, to their advancement. ${ }^{46}$ The right to development today forms an integral part of the canon of human rights and is supported through the UN human rights machinery.

As the DRD and its preparatory work reflect, the right to development typifies a cosmopolitan ethos that reveal its most distinctive and vital component: it is preoccupied, not with a state's duties to its own nationals, but with its duties

\footnotetext{
${ }^{43}$ DRD arts 1(1), 2(1), 2(3), 6(2), 8(1). Poverty reduction, good governance and sustainability are today part of evolutive interpretation of the Declaration.

${ }^{44}$ See, Salomon, Global Responsibility for Human Rights, n 34 above, 121 et seq.; S. P. Marks, 'Misconceptions about the Right to Development,' Special Report, Human Rights and Development, D. Freestone and J. K. Ingram (guest eds), Development Outreach 8 (Washington, DC: The World Bank Institute, October 2006)

${ }^{45}$ DRD, preambular para 16: 'Confirming that the right to development is an inalienable human right and that equality of opportunity for development is a prerogative both of nations and of individuals who make up nations'; art 2(3): 'States have the right and the duty to formulate appropriate national development policies that aim at the constant improvement of the well-being of the entire population and of all individuals, on the basis of their active, free and meaningful participation in development and in the fair distribution of the benefits resulting therefrom.'

$46^{\circ}$ 'The general support of the international community [to a principle of international law] does not of course mean that each and every member of the community of nations has given its express and specific support to the principle. ...' Case Concerning the Gabcikeovo-Nagymaros Project (Hungary v Slovakia) Judge Weeramantry (sep op) ICJ Rep [1997], [95].
} 
to people in far off places. ${ }^{47}$ The duties of international cooperation for addressing poverty and underdevelopment that form its core, distinct from the classical human rights model, are thus inter-state duties with the beneficiaries being the poor of developing countries. Far from being unprecedented under international law, this horizontal aspect of human rights protection has a rich pedigree. ${ }^{48}$ The Global Partnership for Development, envisioned under Millennium Development Goal 8, reflects its current expression.

\section{LESSONS FROM THE SELF-DETERMINATION MODEL}

As remarked earlier, notable parallels can be drawn between the collective right of self-determination and the right to development, beginning with the fact that both are understood as having external and internal dimensions. The principle of selfdetermination, as provided for in the UN Charter had its status elevated to that of a right in the two human rights Covenants only once "the agitation in the context of decolonization raised both the stakes and the normative aspirations of the proponents' ${ }^{49}$ A similar trajectory can be traced with regard to the right to development which began to take shape as a result of the most recent wave of economic globalisation and the remonstrations by developing states against its particular forms of subjugation. Like self-determination, the external aspect of the right to development demands liberation from power and control located outside of the developing state.50 The locus of power today is found among a select minority of states, including via their influence over international financial institutions, within international trade, and by transnational corporations

47 As noted by the Working Group of Governmental Experts drafting the Declaration: 'The right to development implies that states and the international community as a whole should aim at the creation of local and national conditions whereby everyone may enjoy the rights set forth in the Universal Declaration of Human Rights and the International Covenants on Human Rights,' Report of the Working Group of Governmental Experts on the Right to Development (4th session, 9 December 1982) UN Doc E/CN4/1983/11 annex IV, Compilation of Proposals Made by the Experts, Pt I, Section II, art 6; see similarly, art 7. See further, n 34 above, 53 .

48 'When certain states assert that the right to development is a right of states, their argument can only be understood as another way of remarking on their role as a vehicle in the realization of the human right to development. Although a state may need to claim the right to development from the international community before it can be realized by the people to whom it is owed, this does not make the right to development a right of states. It simply reflects the role of the state in an inter-state system.' n 34 above, 116. As Crawford explains, 'the government may be the agent through which the right can be vindicated; however, it will be acting in a secondary capacity, rather than as the holder of the right.' J. Crawford, 'Some Conclusions' in J. Crawford (ed), The Rights of Peoples (Oxford: Clarendon Press, 1988) 167. 'The state becomes the plenipotentiary or international dimension of peoples...' L. A. Obiora, 'Beyond the Rhetoric of a Right to Development' (1996) 18 Law \& Policy 3-4 in M. wa Mutua, L.A. Obiora, and R. J. Krotoszynski Jr. (eds), Special Issue on the Right to Development, 369.

49 P. Alston, 'Peoples' Rights: 'Their Rise and Fall,' in P. Alston (ed), Peoples' Rights (Oxford: Oxford University Press, 2001) 261.

50 The DRD also emphasises the integrated nature of these two rights, both of which have their roots in struggles for liberation from external power and control. Article 1(2) of the Declaration holds that the right to development 'implies the full realization of the right of peoples to self-determination.' 
headquartered in industrialised countries. Collectively they constitute what one commentator defines as 'active networks of global patronage and power'. 51

In view of the importance of the right of self-determination it has obtained a status in international law whereby every state is held to have a legal interest in its protection. In the East Timor case, the International Court of Justice recognised the 'irreproachable' erga omnes character (providing an obligation owed towards all) of the principle of self-determination of peoples as evolved from the UN Charter. ${ }^{52}$ It stated likewise in its 2004 advisory opinion on the Construction of a $W$ all in the Occupied Palestinian Territory, ${ }^{53}$ a position consistent with its view on the principle taken in previous cases. ${ }^{54}$

While there exist a few remaining examples of external self-determination (due to ongoing foreign occupation and the perpetration of gross violations of human rights providing the legitimating conditions for secession), this dimension of self-determination was for the most part addressed by decolonisation. Today, much of the attention focuses on its internal application - the right to democratic governance of the people or constituent groups within the state in relations with their own government. The right to political self-determination was the meta-right of the twentieth century in which the responsibility of the international community in giving it effect was clearly recognised. The right to 'self-determined development' is the meta-right of the twenty-first century, advocating nothing short of a place that allows for the functional equality of representative developing states on the international stage. Like the ius cogens principle of self-determination the right to development is defined by a prominent external dimension, with its legal parameters taking shape in this period of indefensible world poverty.

\section{CONCLUSION}

All aspects of contemporary life are influenced by the world beyond our borders and international human rights law is no exception. This truism invites a shift in mindset and demands that we inquire into the responsibilities, not merely of a developing state to its own people, as important as that is, but of the international

\footnotetext{
51 U. Baxi, Human Rights in a Posthuman World (Delhi: Oxford University Press, 2007) Ch. 4, The Development of the Right to Development, 153.

${ }^{52}$ Case Concerning East Timor (Judgment) (Portugal v Australia) ICJ Rep [1995], [29].

53 The Court would observe that the obligations violated by Israel include certain obligations erga omnes. As the Court indicated in the Barcelona Traction case, such obligations are by their very nature "the concern of all States" and, "[i]n view of the importance of the rights involved, all States can be held to have a legal interest in their protection" (Barcelona Traction, 33).' The obligations erga omnes violated by Israel are the obligation to respect the right of the Palestinian people to self-determination, and certain of its obligations under international humanitarian law. Legal Consequences of the Construction of a Wall in the Occupied Palestinian Territory, ICJ Adv Op [2004], [155-156].

54 Legal Consequences for States of the Continued Presence of South Africa in Namibia (South-West Africa) notwithstanding Security Council Resolution 276 (1970) Adv Op, ICJ Rep [1971], [52-53]; Western Sabara, ICJ Adv Op [1975], [54-59].
} 
community of states. The structures that determine access to wealth and opportunity force us to question the circumstances under which various states might legitimately - and legally - constitute duty-bearers and what the scope of those duties might be. As we seek a meaningful application of the human rights norms articulated to shield those in need against the excesses of globalisation, we are confronted with both the significance of these standards, and the need for their evolutionary interpretation and improved enforcement.

The ideas of equity that animate the right to development are heretical to those with power and advantage since it proposes - in the language of international human rights - modifications to the very system that provides for their dominance. Yet, like the right of self-determination, the right to development while at times contentious and somewhat unconventional in its approach to human rights might in our present climate be recognised as a right without which a range of other rights cannot be enjoyed. 